\title{
Correction to: Deep learning frameworks to learn prediction and simulation focused control system models
}

\section{Turcan Tuna $^{1} \cdot$ Aykut Beke ${ }^{1} \cdot$ Tufan Kumbasar $^{1}$ (I)}

Published online: 22 May 2021

(C) Springer Science+Business Media, LLC, part of Springer Nature 2021

\section{Correction to: Applied Intelligence.} https://doi.org/10.1007/s10489-021-02416-0

The acknowledgment in the original article unfortunately is missing.

This research is supported by the project (118E807) of Scientific and Technological Research Council of Turkey (TUBITAK).

Publisher's note Springer Nature remains neutral with regard to jurisdictional claims in published maps and institutional affiliations. 